\title{
Ethical Consideration for Counsellor Practice as Perceived by Student Counsellors in Nigerian Universities
}

\author{
A. E. Oghounu \\ Department of Guidance and Counselling, \\ Delta State University, Abraka, Nigeria \\ E. E. Enakpoya \\ Department of Guidance and Counselling, \\ Delta State University, Abraka, Nigeria
}

DOI: https://doi.org/10.36941/jesr-2020-0114

Abstract

The paper examined the perception of student counsellors studying Guidance and Counselling in various Nigerian Universities on ethical codes which should guide and protect the counselling profession. Four research questions were raised to guide the study and two corresponding hypotheses were tested at 0.05 level of significance. The study adopted the descriptive survey design, with a sample of 1,50o students, drawn from selected Nigerian universities using the multistage sampling technique. The instrument used to gather data for the study was a 50 item questionnaire constructed by the researcher. The psychometric properties were determined and found adequate for use. The test-re-test method was applied to determine reliability which yielded $r=0.88$. Senior lecturers in the Department of Guidance and Counselling ascertained content and construct adequacy of the instrument. Data collected were analysed using mean and standard deviation to answer research questions and t-test to test the hypotheses. The study found out that respondents perceived counselling codes highly irrespective of their gender and religious beliefs although male respondents showed stronger agreement. It was therefore recommended that the Counselling Association of Nigeria should develop counselling ethical codes for professional counselling practice in Nigeria without considering any bias for gender and religion.

Keywords: Counselling; Ethical Codes; Student Counsellors; Undergraduates; Nigerian Universities

\section{Introduction}

The issue of ethical codes for counselling practitioners all over the world has attracted attention among practitioners in the counselling profession. It is no wonder that Stewart (2013) remarked that "Counselling and Psychotherapy have incurred criticism because of the lack of a common frame of reference for practitioners". Right from the history of the birth of counselling as a profession, different bodies in different countries have formulated their own guidelines, reference and ethical codes. For instance, the British Association for Counselling and Psychotherapy (BACP) has its own guideline for members just as others like the counselling and psychotherapy in Scotland (COSCA), New Zealand Association of Counsellors (NZAC) and the American Counselling Association (ACA) have their own regulatory guidelines and references. The Nigerian experience is not too different. In Nigerian, the body 
under which counselling practitioners gather and are regulated is the Counselling Association of Nigeria (CASSON).

The history of the existence of CASSON dates back to 1975 when its acronym was CAN. Makinde (1991) contended that the Counselling Association of Nigeria has not evolved its own counselling ethical codes for counselling practices and hence the Association is infiltrated with untrained and unqualified practitioners. This reason accounts for why members of the Association in Nigeria are largely secondary school teachers and lecturers in Colleges of Education and Faculty of Education in universities. It should be observed too that counselling has not sufficiently grown out of school setting practice in Nigeria.

If counselling practice must grow beyond its present school setting dominated service to nonschool setting service in hospitals, prisons, rehabilitation centres, remand homes, family, industry, business, community, forensic, military, sports and professions outside education, then, there must be a set of counselling ethical codes put together by professional counsellors to guide and regulate the counselling profession in Nigeria. For example, the American Counselling Association (ACA) serves more than 55,00o members of various practice settings, such as mental health counselling, marriage and family counselling, addictions and substance use disorder counselling, school counselling, rehabilitation counselling, fertility counselling, genetic counselling, HIV/AIDS counselling, career and employment counselling. The Association also accommodates student counsellors and counselling professors (Wikipedia, 2017).

Counselling ethical codes, according to Collins (2007) are developed by professional counselling Association to protect the public from unethical practices, to guide counsellors in ethical decisions and to set standards for professional practice. Counselling ethical codes are standards by which counsellors are evaluated and disciplined. The reputation of a professional body depends on how robust are the ethics guiding it and the level of compliance by its members. Counselling ethical codes are generally grouped under therapeutic relationship with clients, the competence of counsellors, responsibilities, ethical decisions, and boundaries (Stewart, 2013). Stewart (2013) went further to construct what should constitute counselling ethics in line with the international code of medical ethics as follows:

On therapeutic relationship: that counsellors should state clearly and explicitly contracts with clients, that counsellors should use their skills to discourage clients from being dependent on the counsellor and the relationship, that counsellors should use their skills to encourage personal autonomy of the client, that counsellors should not exploit clients sexually, that counsellors should not collude with clients against other people, that counsellors should handle transference and countertransference skilfully to the benefit of both clients and professional practice, that counsellors do not impose their own values or attitude change on clients, that counsellors should ensure that their clients are physically and psychologically safe with them, that counsellors do not intrude, coerce or persuade clients in taking their own decisions, that counsellors discuss the need for regular supervision with them, that counsellors must make explicit to clients the nature and extent of confidentiality of records, information and interaction to third parties.

On competence that counsellors should: recognize and work within limits of competence and training, regularly update their knowledge, experience and technical skills, seek regular supervision from superiors, colleagues and professional body, know when to refer clients and to whom.

On Responsibilities, that the counsellor should show responsibility to their clients by maintaining their effectiveness and ability, themselves to stay fresh and protect their private, family and social life, the counselling relationship by monitoring their performance, to their clients through personal and professional development, to their colleagues and other professionals in various fields, to the wider community to avoid reducing confidence in counselling, to know and work within the laws of the country or ethnic group, to know what the laws of the land require in client confidentiality.

On Protecting the Profession in media, counsellors should: make sure that announcements and advertisements are accurate, make sure that research materials and writings, preserve and secure client anonymity, make sure that conflicts in ethics are resolved through discussion, that counsellors should ensure that counselling relationship does not exploit clients. 
On ethical decisions: counsellors should ensure that they apply ethical codes to practical problems not necessarily on the broad prescription of professional bodies.

On boundaries: the counsellor should be well guided by ethical codes, not personal desires, idiosyncrasies or religious beliefs.

The issue in question is whether the Counselling Association of Nigeria has truly developed counselling ethical codes for the professional practices of its members. It is important to note that a task force was set up by CAN at the Enugu Conference in 1983 to review the ethical standards of the 1988 edition of American Association for Counselling and Development (AACD) and its development from National Vocational Guidance Association (NVGA), American Personnel and Guidance Association (APGA) and to the present status as American Counselling Association (ACA) in order to come up with a standard counselling ethical codes for the Counselling Association of Nigeria, (Makinde, 1991). Despite various attempts by Successive Executive Officers of CASSON, especially the efforts of the presidency of Professor Ibrahim Kolo 2011 - 2014, the researcher is not aware of a blueprint as a document for a standard counselling ethical code for counselling practitioners in Nigeria, developed by the Counselling Association of Nigeria, (CASSON). It is the assumption of this study that what should make up ethical codes for practising counsellors should also derive from the views of student counsellors about what the ideal counsellor should be. Student counsellors are those who are currently taking Guidance and Counselling as a course of study in Nigerian Universities at both undergraduate and postgraduate levels. They are those who will graduate and eventually practice and comply with the ethics which are formulated today.

\subsection{Statement of Problem}

Generally, the purpose of ethical codes for counselling practise should be to facilitate members of the counselling Association to achieve enhancement of the quality of life in society. Counselling ethical codes according to Stewart (2013) should also help to promote building and developing professional counselling, to advance the profession for the purpose of service to the society and to earn respect for human dignity and the profession. Ethical codes are developed for a profession by its Association and members, hence the development of ethical codes for counselling practice by the ACA, NZAC, BACP and COSCA.

It is, therefore, the responsibility of the Counselling Association of Nigeria to develop ethical codes to guide, protect and to set standards for counselling practice for its members. The process of achieving this has been ongoing and evolving. It is the assumption of the researcher that the Nigerian society is far changing socially, technologically, politically, educationally, vocationally and in healthrelated issues. All these changes have far-reaching consequences for educational practices, fashion, attitudes and general behaviour of the people in what is popularly referred to as $2 \mathbf{1}^{\text {st }}$-century civilization. The researcher believes that the perception of student counsellors in various universities in Nigeria who are largely affected by the $21^{\text {st }}$-century civilization and who are going to constitute a majority of members of the Counselling Association of Nigeria on what should constitute standard counselling ethics for CASSON members be sought.

The student counsellors today are those who have to comply tomorrow. Given the present social and religious behaviour of the $21^{\text {st }}$-century student counsellor in the university and society with the present so-called permissiveness in morality, freedom of worship and religious belief, sexual orientations, expressions in fashion, art, and speech, the researcher is left to wonder if personal idiosyncrasy will not affect acceptability and compliance with what should be standard ethical codes for counsellors in Nigeria.

The student counsellor represents all these changes and the $21^{\text {st }}$-century behaviour of people and professionals. Student counsellors have certain characteristics. These include gender, religious affiliation, level of study, experience, marital status and various family backgrounds. The most permeating and pervading of these variables, gender and religion of student counsellors. These variables are capable of influencing the way student counsellors perceive counselling ethical codes. The 
problem of this study put in statement form, therefore, is whether gender and religion of student counsellors will influence their perception of counselling ethical codes developed by the Counselling Association of Nigeria to regulate counselling practice in Nigeria.

\section{$1.2 \quad$ Research Questions}

The following research questions guided the study:

i. What is the perception of Male student counsellors in Nigerian universities on counselling ethical codes for counselling practice in Nigeria?

ii. What is the perception of female student counsellors in Nigerian universities on counselling ethical codes for Counselling practice in Nigeria?

iii. What is the perception of Christian student counsellors in Nigerian universities on counselling ethical codes for Counselling practice in Nigeria?

iv. What is the perception of Muslim student counsellors in Nigeria Universities on counselling ethical codes for Counselling practice in Nigeria?

\subsection{Hypotheses}

The following hypotheses were tested at 0.05 level of significance.

1. There is no significant statistical gender difference in the perception of student counsellors on counselling ethical codes for Counselling practice in Nigeria.

2. There is no significant statistical difference between the perception of Christian and Muslim student counsellors on counselling ethical codes for Counselling practice Nigeria.

\section{Methods}

The study adopted a descriptive survey research design. The population of the study was all students at the undergraduate and postgraduate level who are taking guidance and counselling as a course of study in Private and Public Universities in Nigeria. The sample used for the study was 1,50o students randomly drawn using the multistage sampling technique. First, Universities were stratified into the six geopolitical zones in Nigeria under public and private ownership. There is a total of 153 universities in Nigeria of which 40, 45 and 68 are owned by federal, state and private individuals/organisations respectively (Mafiana, 2017). Five universities were sampled from each geopolitical zone making a total of 30 universities from which 50 students each at various were randomly sampled.

Data were collected using a self-constructed questionnaire tagged counselling ethics perception scale (CEPS). It consisted two parts; A and B. Part A has items which sought demographic information of the respondent while part B contains 50 items which are statements about the therapeutic relationship of the counsellor with his clients, the competence of the counsellor, the responsibilities of the counsellor to himself, the client and the public, ethical decisions and boundaries. Respondents are to react to the items on a four-point scale ranging from 1 for strongly disagree to 1 for strongly agreed.

The psychometric properties of the instrument were determined. Face validity was ascertained for content and construct adequacy by senior lecturers in the Department of Guidance and counselling, Delta state university Abraka while reliability was established with a test-re-test reliability technique which yielded $\mathrm{r}=0.88$, certified high and adequate for use.

Administration of the instrument was facilitated by the researcher and the assistance of Executive Officers of the Student Counselling Association of Nigeria (CASSON) of each state. The exercise lasted four weeks. Data collected were analysed using mean to answer the research questions and t-test was computed to test the hypothesis at 0.05 level of significance. 


\section{Results}

Table 1: Mean rating of the perception of student counsellors on counselling ethics for counselling practice in Nigeria

\begin{tabular}{|c|c|c|c|c|c|c|c|c|c|c|c|c|}
\hline $\begin{array}{l}\text { S/N Perception of Student Counsellors on the Counselling Ethics for } \\
\text { Practicing Counsellors in Nigeria }\end{array}$ & & Gale & Rema & & & Rema & Mu & 1slim & Rem & & $\begin{array}{l}\text { ristia } \\
\text { n }\end{array}$ & \\
\hline & $\mathbf{N}$ & Mean & & $\mathbf{N}$ & Mean & & $\mathbf{N}$ & Mean & & $\mathbf{N}$ & Mean & \\
\hline 1. The Counsellor should be a university graduate & 670 & 3.72 & High & 830 & 3.61 & High & 658 & 3.69 & High & 842 & 3.64 & High \\
\hline 2. The Counsellor should have a degree in counselling & 670 & 3.75 & High & 830 & 3.47 & High & 658 & 3.60 & High & 842 & $3 \cdot 59$ & High \\
\hline 3. The Counsellor should have additional professional qualifications & 670 & 3.26 & High & 830 & 3.24 & High & 658 & 3.26 & High & 842 & 3.24 & High \\
\hline 4. The Counsellor should update his knowledge and skills & 670 & $3.5^{8}$ & High & 830 & $3 \cdot 55$ & High & 658 & 3.57 & High & 842 & 3.55 & High \\
\hline 5. The Counsellor should attend annual conferences of his professional body & 670 & 3.66 & High & 830 & 3.61 & High & 658 & 3.64 & High & 842 & 3.62 & High \\
\hline 6. The Counsellor should be a member of his professional body & 670 & 3.63 & High & 830 & 3.53 & High & 658 & $3 \cdot 58$ & High & 842 & 3.57 & High \\
\hline 7. The Counsellor should be licensed to practice & 670 & 3.70 & High & 830 & 3.60 & High & 658 & 3.65 & High & 842 & 3.64 & High \\
\hline 8. The Counsellor should be equal among his professional colleagues & 670 & 3.32 & High & 830 & 3.18 & High & 658 & 3.23 & High & 842 & 3.25 & High \\
\hline 9. The Counsellor should be competent & 670 & 3.80 & High & 830 & 3.61 & High & 658 & 3.72 & High & 842 & 3.68 & High \\
\hline 10. The Counsellor should be versatile and current with global issues. & 670 & 3.73 & High & 830 & $3 \cdot 54$ & High & 658 & 3.64 & High & 842 & 3.62 & High \\
\hline 11. The Counsellor should be trusted & 670 & 3.83 & High & 830 & 3.77 & High & 658 & 3.80 & High & 842 & 3.79 & High \\
\hline 12. The Counsellor should keep official secrets & 670 & 3.86 & High & 830 & 3.67 & High & 658 & $3 \cdot 77$ & High & 842 & 3.74 & High \\
\hline 13. Clients should have confidence in the Counsellor & 670 & 3.60 & High & 830 & 3.50 & High & 658 & $3 \cdot 57$ & High & 842 & 3.53 & High \\
\hline 14. The Counsellor should be genuine & 670 & 3.74 & High & 830 & 3.69 & High & 658 & 3.73 & High & 842 & 3.69 & High \\
\hline 15. The Counsellor should be patient with his clients & 670 & 3.70 & High & 830 & 3.65 & High & 658 & 3.70 & High & 842 & 3.65 & High \\
\hline 16. The Counsellor should be caring & 670 & 3.61 & High & 830 & 3.59 & High & 658 & 3.64 & High & 842 & 3.57 & High \\
\hline 17. The Counsellor should respect the client's opinion & 670 & $3 \cdot 51$ & High & 830 & 3.40 & High & 658 & 3.49 & High & 842 & 3.42 & High \\
\hline 18. The Counsellor should show unconditional regards his clients & 670 & $3 \cdot 54$ & High & 830 & 3.45 & High & 658 & 3.52 & High & 842 & 3.47 & High \\
\hline $\begin{array}{l}\text { 19. The Counsellor should protect his clients' rights as allowed by the laws of } \\
\text { the land }\end{array}$ & 670 & 3.57 & High & 830 & 3.46 & High & 658 & 3.53 & High & 842 & 3.49 & High \\
\hline 20. The Counsellor should understand the client & 670 & 3.46 & High & 830 & 3.60 & High & 658 & $3 \cdot 55$ & High & 842 & $3 \cdot 5^{2}$ & High \\
\hline 21. The Counsellor should have integrity & 670 & 3.83 & High & 830 & $3 \cdot 77$ & High & 658 & 3.81 & High & 842 & 3.78 & High \\
\hline 22. The Counsellor should be upright morally & 670 & 3.77 & High & 830 & 3.64 & High & 658 & 3.71 & High & 842 & 3.69 & High \\
\hline 23. Clients should have no reason to doubt the morality of the Counsellor & 670 & $3 \cdot 31$ & High & 830 & $3 \cdot 34$ & High & 658 & $3 \cdot 35$ & High & 842 & $3 \cdot 31$ & High \\
\hline 24. The Counsellor should not seduce clients & 670 & 3.67 & High & 830 & 3.60 & High & 658 & 3.66 & High & 842 & 3.60 & High \\
\hline 25. The Counsellor should not exploit his clients financially & 670 & 3.69 & High & 830 & $3 \cdot 57$ & High & 658 & 3.64 & High & 842 & 3.62 & High \\
\hline 26. The Counsellor should not promote any form of malpractice & 670 & 3.72 & High & 830 & 3.72 & High & 658 & 3.75 & High & 842 & 3.70 & High \\
\hline 27. The Counsellor should be impartial & 670 & 3.54 & High & 830 & 3.38 & High & 658 & 3.45 & High & 842 & 3.45 & High \\
\hline 28. The Counsellor should dress decently & 670 & 3.79 & High & 830 & 3.70 & High & 658 & 3.76 & High & 842 & 3.72 & High \\
\hline 29. The Counsellor should not be judgemental & 670 & 3.85 & High & 830 & 3.63 & High & 658 & 3.73 & High & 842 & 3.72 & High \\
\hline 30. The Counsellor should keep discussion he had with his clients private & 670 & 3.03 & High & 830 & 3.15 & High & 658 & 3.10 & High & 842 & 3.09 & High \\
\hline $\begin{array}{l}\text { 31. The Counsellor should maintain a workable relationship with other } \\
\text { Counsellors }\end{array}$ & 670 & 3.66 & High & 830 & 3.50 & High & 658 & 3.58 & High & 842 & 3.57 & High \\
\hline $\begin{array}{l}\text { 32. The Counsellor should refer clients who have severe financial problems to } \\
\text { appropriate quarters }\end{array}$ & 670 & 3.36 & High & 830 & 3.26 & High & 658 & 3.31 & High & 842 & 3.29 & High \\
\hline $\begin{array}{l}\text { 33. The Counsellor should refer those who need legal advice to appropriate } \\
\text { quarters }\end{array}$ & 670 & 3.41 & High & 830 & 3.43 & High & 658 & 3.43 & High & 842 & 3.42 & High \\
\hline $\begin{array}{l}\text { 34. The Counsellor should refer those who need financial guidance to } \\
\text { appropriate quarters where they can get help }\end{array}$ & 670 & 3.42 & High & 830 & 3.52 & High & 658 & 3.51 & High & 842 & 3.45 & High \\
\hline $\begin{array}{l}\text { 35. The Counsellor should refer to those who need medical evaluation and } \\
\text { treatment to hospitals and institutions where they can get help. }\end{array}$ & 670 & 3.72 & High & 830 & 3.63 & High & 658 & 3.69 & High & 842 & 3.65 & High \\
\hline $\begin{array}{l}\text { 36. The Counsellor should refer clients with severe or bizarre aggressive } \\
\text { behaviour to homes and institutions where they can get help. }\end{array}$ & 670 & 3.36 & High & 830 & 3.35 & High & 658 & 3.38 & High & 842 & 3.33 & High \\
\hline $\begin{array}{l}\text { 37. The Counsellor should refer clients who may stir up strong feelings of } \\
\text { dislike in him }\end{array}$ & 670 & 3.09 & High & 830 & 2.95 & High & 658 & 3.05 & High & 842 & 2.98 & High \\
\hline 38. The Counsellor should refer clients to other counsellors of their choice & 670 & 2.93 & High & 830 & 2.78 & High & 658 & 2.87 & High & 842 & 2.83 & High \\
\hline $\begin{array}{l}\text { 39. The Counsellor should not claim to be able to handle all concerns of } \\
\text { clients }\end{array}$ & 670 & 3.42 & High & 830 & 3.38 & High & 658 & 3.44 & High & 842 & 3.37 & High \\
\hline $\begin{array}{l}\text { 40. The Counsellor should terminate counselling in a problem which appears } \\
\text { to be getting worse despite intervention }\end{array}$ & 670 & 2.96 & High & 830 & 2.99 & High & 658 & 3.00 & High & 842 & 2.96 & High \\
\hline 41. The Counsellor should refer cases which are beyond his area of expertise & 670 & $3 \cdot 5^{8}$ & High & 830 & 3.42 & High & 658 & 3.49 & High & 842 & $3 \cdot 50$ & High \\
\hline $\begin{array}{l}\text { 42. The Counsellor should be familiar with community resources and persons } \\
\text { to whom referral can be made. }\end{array}$ & 670 & 3.56 & High & 830 & 3.44 & High & 658 & 3.51 & High & 842 & 3.48 & High \\
\hline $\begin{array}{l}\text { 43. The Counsellor should be able to know and avoid situations of } \\
\text { vulnerabilities }\end{array}$ & 670 & 3.54 & High & 830 & 3.43 & High & 658 & 3.50 & High & 842 & 3.46 & High \\
\hline $\begin{array}{l}\text { 44. The Counsellor should be recognised and avoid danger signals from self } \\
\text { and clients }\end{array}$ & 670 & 3.47 & High & 830 & 3.38 & High & 658 & 3.46 & High & 842 & 3.39 & High \\
\hline 45. The Counsellor should not accept gifts and frequent praises from clients & 670 & 3.21 & High & 830 & 3.42 & High & 658 & 3.34 & High & 842 & $3 \cdot 32$ & High \\
\hline $\begin{array}{l}\text { 46. The Counsellor should set limits on issues to discuss, frequency, place and } \\
\text { time of meetings and physical contact with students }\end{array}$ & 670 & 3.60 & High & 830 & 3.46 & High & 658 & 3.55 & High & 842 & 3.50 & High \\
\hline 47. The Counsellor should not handle criminal cases & 670 & 2.90 & High & 830 & 2.75 & High & 658 & 2.88 & High & 842 & 2.77 & High \\
\hline 48. The Counsellor should not compare clients with his/her spouse & 670 & 3.25 & High & 830 & 3.29 & High & 658 & 3.29 & High & 842 & 3.26 & High \\
\hline 49. The Counsellor should resist seductive behaviour from clients & 670 & 3.70 & High & 830 & 3.50 & High & 658 & 3.60 & High & 842 & 3.58 & High \\
\hline 50. The Counsellor should use all his skills to discourage client dependency. & 670 & 3.53 & High & 830 & $3 \cdot 37$ & High & 658 & 3.43 & High & 842 & 3.45 & High \\
\hline Grand Mean & & 3.53 & & & $3 \cdot 4$ & & & $3 \cdot 50$ & & & 3.4 & \\
\hline
\end{tabular}




\subsection{Answer to Research Questions}

Research Question 1: what is the perception of male student counsellors on the counselling ethics for practising counsellors in Nigeria?

The research question was answered using the mean score of male respondents as presented in table 1. The mean score of 3.53 for male student counsellors was high as was for all items on the questionnaire. The answer to the research question, therefore, is that male student counsellors perceive counselling ethical codes highly.

Research Question 2: What is the perception of female student counsellors on the counselling ethics for practising counsellors in Nigeria?

The research question was answered using the mean score of female respondents as presented in table 1. The mean score of 3.45 for female student counsellors was high as was for all items on the questionnaire. The answer to the research question, therefore, is that female student counsellors perceived counselling ethical codes highly.

Research Question 3: What is the perception of Christian student counsellors on the counselling ethics for practising counsellors in Nigeria?

The research question was answered using the mean score of Christian respondents as presented in table 1. The mean score of 3.50 for Christian student counsellors was high as was for most of the items on the questionnaire. The answer to the research question, therefore, is that Christian student counsellors perceived counselling ethical codes highly.

Research Question 4: What is the perception of Muslim student counsellors on the counselling ethics for practising counsellors in Nigeria?

The research question was answered using the mean score of Muslim respondents as presented in table 1. The mean score of 3.47 for Muslim student counsellors was high as for most items on the questionnaire. The answer to the research question, therefore, is that Muslim student counsellors perceived counselling ethical codes highly.

\subsection{Test of Hypotheses}

3.2.1 Hypothesis 1: There is no significant gender difference in the perception of student counsellors on the counselling ethics for practising counsellors in Nigeria.

Result of t-test analysis is presented in Table 2

Table 2: t-test analysis of the difference in the perception of male and female student counsellors on the counselling ethics for practising counsellors in Nigeria

\begin{tabular}{lcccccc}
\hline Gender & N & Mean & SD & t & P & Decision \\
\hline Male & 670 & 3.53 & 0.31 & & & \\
Female & 830 & 3.45 & 0.46 & 3.77 & 0.00 & Significant \\
\hline
\end{tabular}

Since $\mathrm{P}<0.5$, the hypothesis is therefore rejected meaning that there is a significant difference between male and female student counsellors on the counselling ethics for practising counsellors in Nigeria.

\subsubsection{Hypothesis 2: There is no significant difference in the perception of Christian and Muslim student counsellors on the counselling ethics for practising counsellors in Nigeria}

Table 3: t-test analysis of the difference in the perception of Christian and Muslim student counsellors on the counselling ethics for practising counsellors in Nigeria

\begin{tabular}{lcccccc}
\hline Religion & N & Mean & SD & t & P & Decision \\
\hline Islam & 658 & 3.50 & 0.39 & & & \\
Christianity & 842 & 3.47 & 0.41 & 1.57 & 0.12 & Not Significant \\
\hline
\end{tabular}


Since $\mathrm{P}>0.05$, the hypothesis is therefore accepted meaning that there is no significant difference in the perception of Christian and Muslim student counsellors on the counselling ethics for practising counsellors in Nigeria

\section{Discussion}

Result of data analysis of this study revealed that student counsellors in Nigerian universities perceive counselling ethical codes very highly irrespective of their differences in gender and religious beliefs. In fact, male and female student counsellors indicated strong agreement to all the items which described what the ideal counselling ethical codes for professional counselling practices should be as in the questionnaire used to gather data for the study. However, male student counsellors were in stronger agreement on certain items of the instrument. It is not surprising therefore, that the hypothesis of no significant difference between male and female student counsellors on their perception of counselling ethics was rejected. It should be noted that this was in spite of the fact that female student counsellors in the study were in greater number.

This finding is in agreement with that of McDaniel, Schoeps \& Lincourt (2001), who investigated gender perception of employees on organizational ethics. Their study revealed that males were more in agreement than females that the firm had an ethical environment, and that males were in stronger agreement on some of the items on the scale used for the survey. One reason that can be given to explain the finding of the present study is the fact that the female gender cannot easily compromise their lifestyles especially in fashion, emotions, comfort and convenience for conformity to ethical codes. This is why other studies, (Pusavat \& Shapiro, 2007; Fontenelle \& Zinkhan, 1993 and Amatav \& Sharma, 2011) found gender differences in perception of male and female on TV shows, leisure and workplace sexual harassment respectively.

The finding of no significant difference in the perception of counselling ethics by Christians and Muslim student counsellors in this study is not surprising. This is so because Christian and Muslim religions are founded on ethical codes and commandment of God which of course are not too different from those adopted by the counselling profession. For instance, religious ethical codes emphasize morality, respect and regard for humanity, empathy, justice, equity, competence and responsibility which also are the hallmark of counselling ethical codes and Muslim and Christian practices (Evans, 2003; Peres, 2007; Bilgrave \& Deluty, 1998; Post, Puchalski \& Larson, 2000; McSherry, Gretton, Draper \& Watson, 2008; Vieten, 2012; McMinn, 1996 and Stewart, 2013).

\section{Conclusion/Recommendation}

The study concluded that male and female student counsellors irrespective of their religious beliefs agreed strongly with the ideal items that should pass for counselling ethical codes to be adopted and developed for professional counselling practice in Nigeria. The study established that gender and religion of professionals do not influence their perception of ethical codes for professional practice. It is therefore recommended that counselling ethical codes should be developed by the Counselling Association of Nigeria to guide and regulate counselling practices in Nigeria without any bias to gender and religion as long as they conform with universal ethical standards that regulate professional counselling practices.

\section{References}

Banerjee, A., \& Bhavana. S. (2011). Gender difference in the perception of workplace sexual harassment among professionals. Industrial Psychiatry Journal, 20(1), 21-24.

Bilgrave, D. P., \& Deluty, R. H. (1998). Religious beliefs and therapeutic orientations of clinical and counselling psychologists. Journal for the Scientific Study of Religion, 37(2), 329-349. 
Collins, G. R. (2007). Christian Counselling; A Comprehensive Guide. Wheaton: Tyndale House Publishers Inc. 8999.

Evans, M. (2003). Christian Counsellors' Views on working with gay and Lesbian clients: integrating religious belief with counselling ethics. www.tandfonline.com $>$ doi $>$ abs

Fontenelle, S. M., \& Zinkhan, G. M. (1993). Gender difference in the perception of leisure. A perceptual model. Advance in Consumer research, 20, 534-550.

Mafiana, C. F. (2017). State Universities and the challenge of relevance. $11^{\text {th }}$ convocation ceremony lecture of the Delta State University, Abraka.

Makinde, I. O. (1991). Review of the 1988 AACD Ethical Standards: Implications for the Counselling Association of Nigeria and Natural Counselling Practice. The Counsellor, 10(1), 8-14.

McDaniel, C., Schoeps, N., \& Lincourt, J. (2001). Organizational Ethics: Perceptions of Employees by Gender. Journal of Business Ethics, 33(3), 245-256.

McMinn, M. R. (1996). Ethics Among Christian Counsellors: A Survey of Beliefs and Behaviours, digitalcommons.georgefox. edu>cgi>viewcontent

McSherry, W., Gretton, M., Draper, P., \& Watson, R. (2008). The ethical basis of teaching spirituality and spiritual care: A survey of student nurses perception. Nurse Education Today, 28(8), 1002-1008.

Post, S. G., Puchalski, C., \& McLarson, D. B. (200o). Physicians and patient spirituality: professional boundaries competence and ethics. American College of Physician Amals of Internal Medicine, 132(7), 578-583.

Pusavat, G. S., \& Shapiro, M. A. (2007). Gender perception Differences for relations portrayed on Television. http://ecommons.cornel.eduhandle.

Refers, J. F. P. (2007). Spirituality, religiousness and psychotherapy. www.sciele.br>scale

Stewart, W. (2013). An A - Z of Counselling Theory Practice. Hampshine: Cengage Learning EMFA. 89-92.

Vieten, C. (2012). Spiritual and Religious Competence for Psychologists and Counsellors. http://www.apa.org>pubs>rel-90032699.

Wikipedia http://en.m.wikipedia.org.wiki/July 3, 201, American Counselling Association http://www.counselling org/about-us/about 3/7/2017. 